\title{
Study of near surface boundary layer characteristics during pre-monsoon seasons using micrometeorological tower observations
}

\author{
S. CHAUDHURI and A. MIDDEY \\ Department of Atmospheric Sciences, University of Calcutta, 51/2 Hazra Road, Kolkata-700 019, India \\ Corresponding author: S. Chaudhuri; e-mail: chaudhuri_sutapa@yahoo.com
}

Received May 3, 2012; accepted September 4, 2012

\begin{abstract}
RESUMEN
El estudio de la capa límite es imperativo, ya que las condiciones meteorológicas adversas en esta parte de la atmósfera afectan el ambiente y diversos aspectos de las actividades de un país, y repercuten en el entorno socioeconómico de una región. Las características de la capa límite superficial se estudian por medio de la variación vertical de flujos de calor, humedad, ímpetu y energía cinética, así como del número de Richardson, durante la temporada previa al monzón (abril-mayo) en Kharagpur ( $22^{\circ} 30^{\prime} \mathrm{N}, 87^{\circ} 20^{\prime}$ E) y Ranchi $\left(23^{\circ} 32^{\prime} \mathrm{N}, 85^{\circ} 32^{\prime} \mathrm{E}\right)$, con datos provenientes de torres de 50 y $32 \mathrm{~m}$ de altura, respectivamente, en días con y sin tormenta. Se observa que la variación temporal de los flujos dentro de la capa límite y la energía cinética en varias alturas logarítmicas son significativas al comparar días con tormenta y sin ella. Los flujos de calor y de ímpetu exhiben picos máximos mientras que el flujo de humedad muestra una disminución súbita justo antes de la tormenta. Las condiciones del viento desempeñan un papel crucial en la estación de Kharagpur, situada tierra adentro en las cercanías del Golfo de Bengala, a diferencia de la estación de Ranchi, ubicada en un terreno montañoso de Chotanagpur. El estudio micrometeorológico de la capa límite supuso un importante hallazgo concerniente a la observación de las tormentas, pues se observó que la razón de la temperatura potencial $(\theta)$ y la temperatura potencial equivalente $(\theta e)$ se mantiene dentro de los límites de un rango crítico de 0.85 a 0.90 durante el tránsito de estos fenómenos.
\end{abstract}

\begin{abstract}
Studying the boundary layer is imperative because severe weather in this portion of the atmosphere impacts on environment and various facets of national activities and affects the socioeconomic scenario of a region. Near surface boundary layer characteristics are investigated through the vertical variation of fluxes of heat, moisture, momentum, kinetic energy and Richardson number during the pre-monsoon season (April-May) at Kharagpur ( $\left.22^{\circ} 30^{\prime} \mathrm{N}, 87^{\circ} 20^{\prime} \mathrm{E}\right)$ and Ranchi $\left(23^{\circ} 32^{\prime} \mathrm{N}, 85^{\circ} 32^{\prime} \mathrm{E}\right)$ with 50 and $32 \mathrm{~m}$ tower data, respectively, on thunderstorm and non-thunderstorm days. The temporal variation of fluxes within the boundary layer and the kinetic energy at different logarithmic heights are observed to vary significantly between thunderstorm and non-thunderstorm days. The heat and momentum fluxes show a maximum peak while the moisture flux shows a sudden attenuation just before the occurrence of thunderstorms. The wind field depicts to play a crucial role at the inland station Kharagpur, which is in the proximity of the Bay of Bengal, compared to the station Ranchi, situated over hilly terrain on Chotanagpur. The micrometeorological study of the boundary layer reveals a significant finding pertaining to observe the passage of thunderstorms. It is observed that the ratio of the potential temperature $(\theta)$ and equivalent potential temperature $(\theta e)$ remains confined within a critical range between 0.85 and 0.90 during the passage of thunderstorms.
\end{abstract}


Keywords: Boundary layer, boundary layer characteristics, tower observation, moist thermodynamic parameter, thunderstorm, thunderstorm forecast, thunderstorm genesis.

\section{Introduction}

The earth's surface is the only boundary in the domain of the atmosphere. The characteristics of the atmosphere near the surface are highly influenced by surface friction, convection, turbulence and its interaction with the free atmosphere. The surface layer is the region at the bottom of the boundary layer where turbulent fluxes vary less than $10 \%$ of their magnitude (Stull, 1988). The growth of the convective boundary layer (CBL) is driven by both surface fluxes of heat and moisture and the entrainment of warm and dry air from the free atmosphere (Kang, 2009). The transfer of energy from the generated mesoscale motions to the CBL turbulence results in the absence of a spectral gap between the two scales (Nieuwstadt and Brost, 1986). One of the most important features of the atmospheric boundary layer (ABL) is the ability to diffuse momentum, heat and moisture across it (Grant, 1986). Boundary layer height, the vertical profiles of the mass flux and the updraft area fraction can be determined from large eddy simulations (LES) (Blackadar, 1962; Brown, 1996). The boundary layer transports water vapor and heat to the free atmosphere, and the kinetic energy of the atmosphere is lost by dissipation (Sutton, 1953). The characteristics of turbulence in the thermally stratified atmospheric surface layer can be expressed in terms of the surface layer similarity theory (Kaimal et al., 1976; Sorbjan, 2008). The turbulent fluxes (Panofsky and Dutton, 1984) of momentum, heat and moisture can be expressed using an analogy to molecular diffusion as:

$$
\begin{aligned}
& \tau=K_{m} \rho \frac{\partial \bar{u}}{\partial z} \\
& H=-K_{h} \rho C_{P} \frac{\partial \bar{\theta}}{\partial z} \\
& E=-K_{q} \rho C_{P} \frac{\partial \bar{q}}{\partial z}
\end{aligned}
$$

where $\tau, H$ and $E$ are the flux of momentum, heat and moisture, respectively; $K_{m}, K_{h}, K_{q}$ are the exchange coefficients of momentum, heat and moisture fluxes, respectively; and $\bar{u}, \bar{\theta}, \bar{q}$ are the means of wind velocity, potential temperature and specific humidity, respectively. $C_{P}$ is the specific heat of air at constant pressure and $\rho$ is the density of air. The fluxes are approximately constant with height in the surface layer (Businger et al., 1971; Deardorff, 1974). The interaction between the low level shear and the gust front is vital for the maintenance of erect updrafts in long-lived convective systems (Rotunno et al., 1988). The friction velocity $u_{*}$ represents the velocity scale. The vertical change in the mean wind can be represented by $u_{*}$ as

$\frac{\partial \bar{u}}{\partial z}=\frac{u_{*}}{k z}$

where $k$ is the von Karman constant. 
Integration of Eq. (4) from $z=z_{0}$ to a height $z$ gives the logarithmic profile of wind:

$\bar{u}=\frac{u_{*}}{k} \ln \frac{z}{z_{0}}$

A non-dimensional parameter, the Richardson number $(R i)$ is used as the indicator of atmospheric stability and represents the relative importance of convective to mechanical turbulence:

$R i=\frac{\left(\frac{g}{T}\right)\left(\frac{\partial \bar{\theta}}{\partial z}\right)}{\left(\frac{\partial \bar{u}}{\partial z}\right)^{2}}$

where $g$ is the acceleration due to gravity and $T$ is the temperature in degree Kelvin. At the critical value of $R i=0.25$, the flow undergoes the transition from laminar to turbulent. The temperature stratification dampens the effect of wind shear for $R i>0.25$. The range $0 \leq R i<0.25$ indicates purely mechanical turbulence. An important thermodynamic parameter for dry atmosphere is potential temperature $(\theta)$, which can be used for comparing the thermodynamic inconsistency of air parcels under different pressure levels. While the latent heat release is involved, $\theta$ is not conserved. The equivalent potential temperature $(\theta e)$, on the other hand, describes the saturated atmosphere that is conserved in the saturated and moist adiabatic expansion (Zhou et al., 2009). $\theta e$ has been widely used in many studies of moist atmospheric processes, such as the analysis of stability (Robinson, 1989), extra-tropical cyclone (Cao and Cho, 1995), squall line (Hertenstein and Schubert, 1991), frontal surface, and rain bands (Gao et al., 2002a, b). Potential temperature $\theta$ is suitable for absolutely dry air and $\theta e$ in general for absolutely saturated, moist air; thus, both $\theta$ and $\theta e$ have limitations regarding their application. However, the real atmosphere is neither totally dry nor completely saturated. It is moist but unsaturated. Gao et al. (2004) defined the atmospheric state as one in which the air is saturated somewhere but not everywhere. The conservation of $\theta$ and $\theta e$ may not thus be properly applied to the moist atmosphere.

\section{Objectives}

In this study the lower $50 \mathrm{~m}$ of the atmospheric boundary layer at Kharagpur ( $22^{\circ} 30^{\prime} \mathrm{N}, 87^{\circ} 20^{\prime} \mathrm{E}$ ) and $32 \mathrm{~m}$ at Ranchi $\left(23^{\circ} 32^{\prime} \mathrm{N}, 85^{\circ} 32^{\prime} \mathrm{E}\right)$ on thunderstorm days are analyzed and compared with non-thunderstorm days having undisturbed boundary layer. Rapid changes in temperature, humidity, wind and pressure gradient are observed during thunderstorm days. The boundary layer becomes inhomogeneous and no equilibrium flow develops within it. These are important differences to the stationary, homogeneous boundary layer, which has been studied quite broadly (Frank, 1994). The $50 \mathrm{~m}$ tall micrometeorological tower situated at Kharagpur and the $32 \mathrm{~m}$ tower at Ranchi provide observations of various important meteorological parameters (temperature, humidity, pressure, wind speed and direction) at different logarithmic heights and net solar radiation, rainfall at a fixed height near the surface. The micrometeorological towers also provide soil temperature and moisture data at different depths.

The objective of this study is to explore the dynamical and thermodynamical characteristics of the surface boundary layer with data of two micrometeorological towers during thunderstorm 
periods of pre-monsoon months (Manohar et al., 1999). Such understanding of the physical/ dynamical processes (Chaudhuri, 2008a, b) in a better way may be helpful to improve the forecast skill (Hong and Pand, 1996; Chaudhuri and Middey, 2009, 2011; Chaudhuri, 2010).

In this study, the moist atmosphere is defined as moist but unsaturated to avoid confusion between the two states of the atmosphere, which is pertinent for the real atmosphere. The phase changes and microphysical processes are difficult to observe and estimate, thus progress in these fields is very limited.

Potential temperature $(\theta)$ and equivalent potential temperature $(\theta e)$ are the parameters representing two different conditions of the atmosphere, i.e. dry and saturated, respectively, but as far as real atmosphere is concerned a moist thermodynamic parameter (MTP), which is the ratio of $\theta$ and $\theta e$ may provide $a$ more realistic measure to atmospheric conditions:

$M T P=\theta / \theta e$

In the present study, MTP is measured within the near surface boundary layer during pre-monsoon months over the two stations having different orography, on thunderstorm and non-thunderstorm days.

\section{Site description and implementation}

The station Kharagpur is located in the Midnapore district of the state of West Bengal, India, 80 $\mathrm{km}$ inland from the Bay of Bengal. It has an average elevation of $29 \mathrm{~m} \mathrm{(95} \mathrm{ft)} \mathrm{asl} \mathrm{(Fig.} \mathrm{1).} \mathrm{During}$ the pre-monsoon months of April and May, the inflow on the shallow layer of moist southerlies or southwesterly wind from the Bay of Bengal near the ground, and dry westerly wind aloft represent the main synoptic conditions over Kharagpur (Fig. 2). Severe local convective storms are the common weather phenomena during the pre-monsoon season (April-May). Storms usually approach the station from a northwest direction. However, very few thunderstorms also approach the station from a southwesterly direction. The surface temperature sometimes exceeds $38{ }^{\circ} \mathrm{C}$. The wind speed and direction show diurnal variation as expected due to sea breeze and land breeze formation (Lohar et al., 1994). This type of weather prevails every day during the months of April and May; however, thunderstorms do not occur every day. Surface trigger and upper air divergent flow are required for the genesis and development of the convective weather leading to thunderstorms. Surface layer characteristics during thunderstorm and non-thunderstorm days show significant variations. On the onset of sea breeze, the general trend observed is a decrease in momentum and heat fluxes with an increasing tendency of moisture flux, which indicates a steady flow of cool moist marine air after the passage of the sea breeze over Kharagpur.

Ranchi station, on the other hand, has a subtropical climate, which is characterized by a hot summer from March to May (mean maximum temperature around $36^{\circ} \mathrm{C}$ ). The northernmost and southernmost parts of the district are covered with hillocks and forests. Altitude of the place varies from 500 to $700 \mathrm{~m}$ asl in general. Ranchi has a humid subtropical climate. However, due to its hilly topography and combination with dense tropical forests, it is known for pleasant climate. The strong westerly flow at $300 \mathrm{hPa}$ is responsible for strong upper air divergence (Fig. 3) over the northeastern part of the country enclosing both stations. 

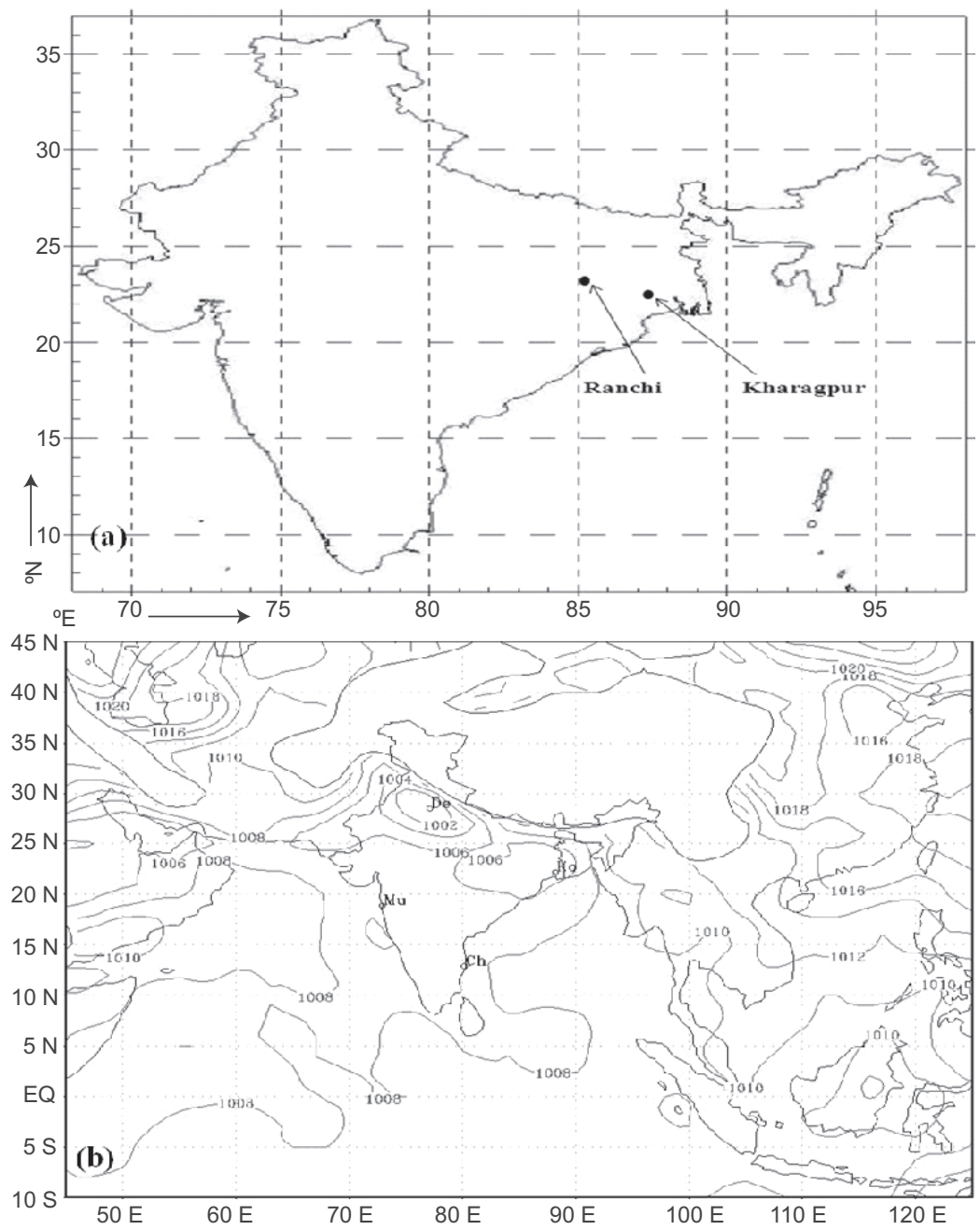

Fig. 1. (a) Location of the micrometeorological towers over Ranchi and Kharagpur. (b) Contours of mean sea level pressure (hPa) during pre-monsoon month April.

Sutton (1953) suggested two parts within the planetary boundary layer (PBL). The first one from surface to $100 \mathrm{~m}$, a region with constant stress, unaffected by Earth's rotation with a wind structure governed by surface friction and a temperature gradient; and the second one above that layer, extending up to $1000 \mathrm{~m}$, where variable shearing stress is observed and wind profile is influenced by a density gradient (buoyancy), Earth's rotation and also surface friction. The fluxes are computed using flux-profile relationships (Eqs. [1]-[3]) from gradient theory near the ground (i.e. $<10 \mathrm{~m}$ ). It can be assumed that, close to the ground, $K_{m}=K_{h}=K_{q}$ (Sutton, 1953). If we assume that the profiles are approximately logarithmic then the fluxes of momentum, heat and moisture take the form

$\frac{\tau}{\rho}=\left[\frac{k}{\ln \left(z_{2} / z_{1}\right)}\right]^{2}\left(\bar{u}_{2}-\bar{u}_{1}\right)^{2}$ 


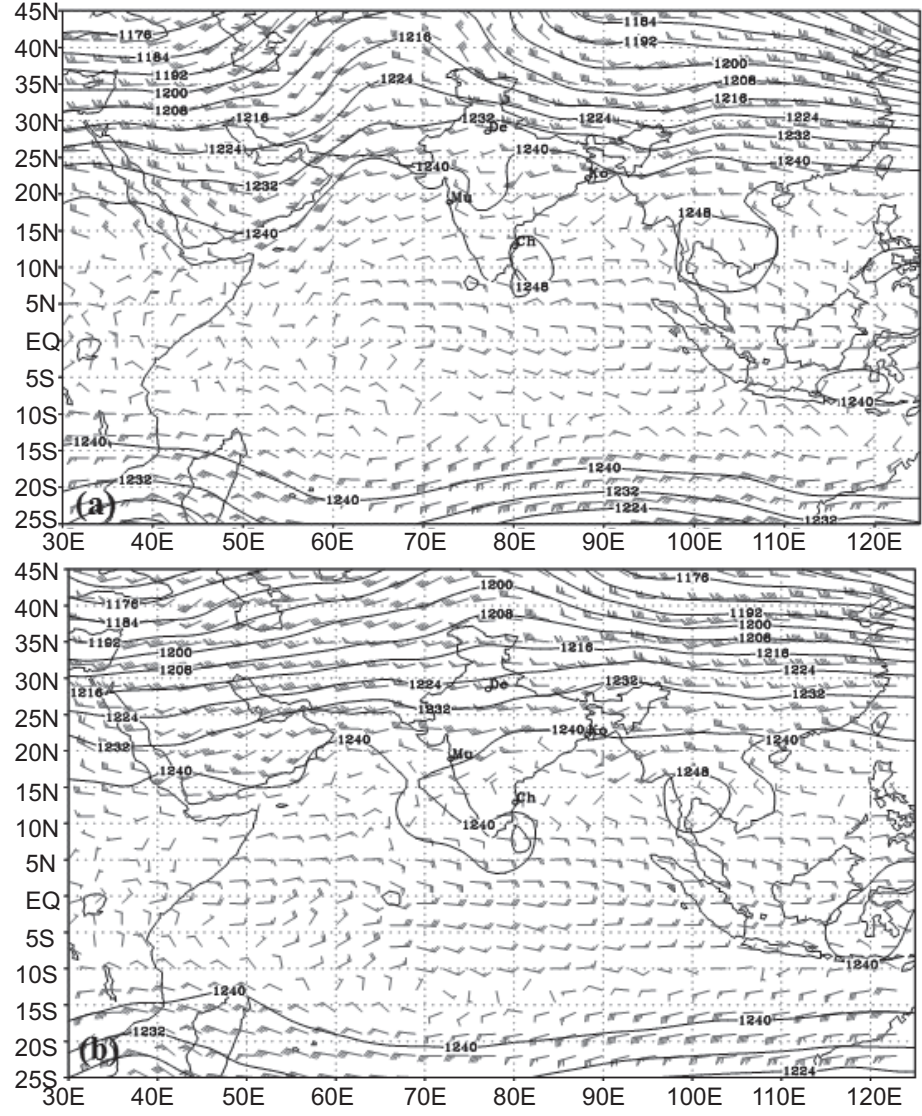

$\frac{H}{\rho}=\left[\frac{k}{\ln \left(z_{2} / z_{1}\right)}\right]^{2}\left(\bar{u}_{2}-\bar{u}_{1}\right)\left(\bar{\theta}_{2}-\bar{\theta}_{1}\right)$

$\frac{E}{\rho}=\left[\frac{k}{\ln \left(z_{2} / z_{1}\right)}\right]^{2}\left(\bar{u}_{2}-\bar{u}_{1}\right)\left(\bar{q}_{2}-\bar{q}_{1}\right)$
Fig. 2. The $200 \mathrm{hPa}$ wind (kt) analysis showing upper air divergent winds at 00:00 UTC on (a) April 26, 2007 (severe thunderstorm over Kharagpur) and (b) April 23, 2007 (no thunderstorm over Kharagpur).

The surface boundary layer fluxes are computed using Eqs. (8), (9) and (10).

\section{Description of the data}

Different sensors are affixed to the micrometeorological tower at six logarithmic heights $(2,4$, 8, 16, 32 and $50 \mathrm{~m}$ ) at Kharagpur. On the other hand, the boundary layer tower contains various sensors at five logarithmic heights $(1,2,8,16$ and 32) at the station Ranchi. The sensors record temperature, relative humidity, wind speed and direction at six levels, as well as net radiation (10 $\mathrm{m})$, pressure, soil temperature, soil moisture and rainfall every three minutes interval. The sensors attached to the micrometeorological tower are: HMP45C-L sensors that measure air temperature and relative humidity at six logarithmic heights; an RM Young barometric pressure sensor (61205) that measures atmospheric pressure; an RM Young wind anemometer (05103-10-L) that measures 

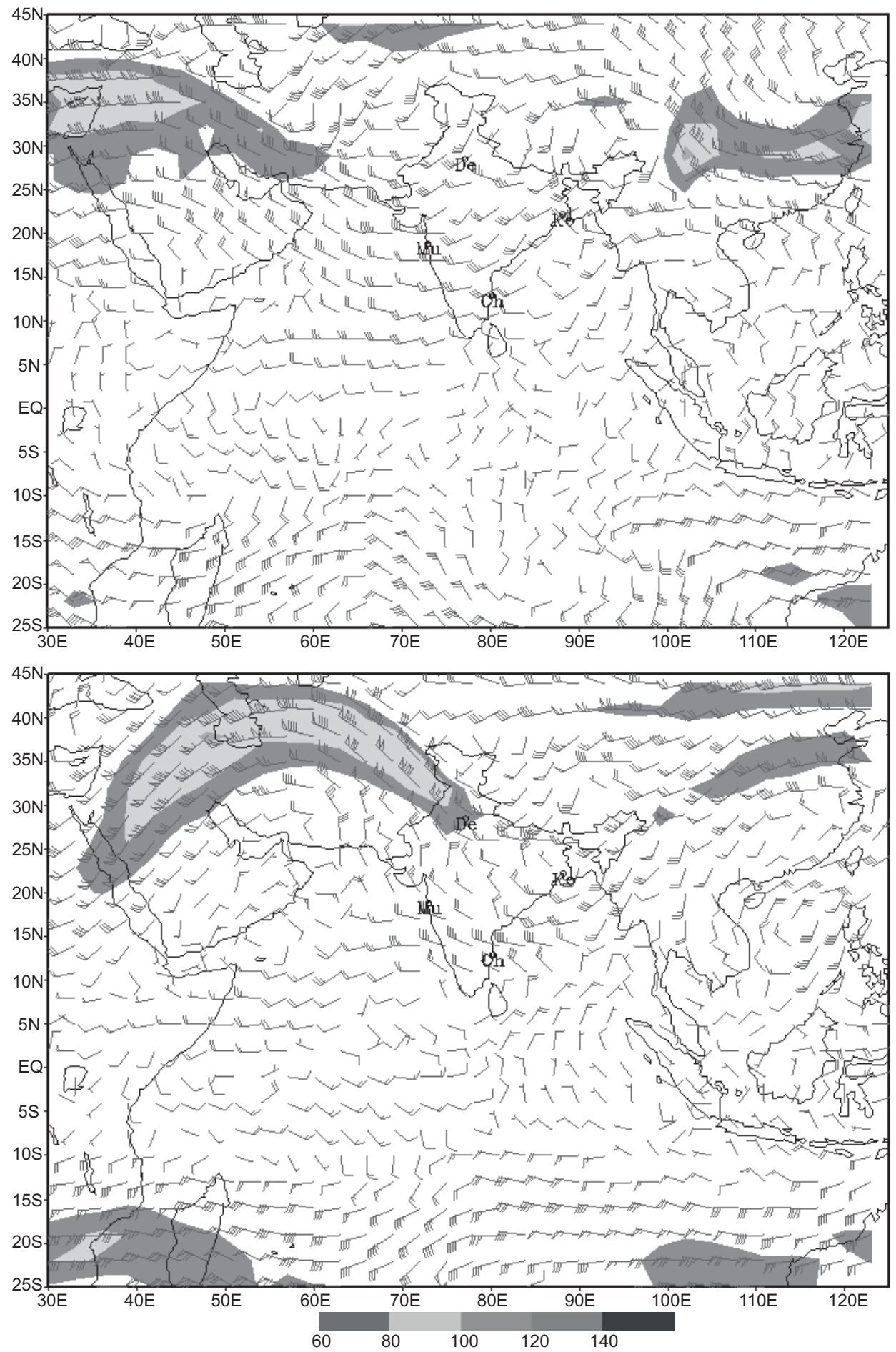

Fig. 3. The $300 \mathrm{hPa}$ wind (kt) analysis showing upper air divergent winds at 00:00 UTC on (a) May 3, 2009 (severe thunderstorm over Ranchi) and (b) May 11, 2009 (no thunderstorm over Ranchi). 
wind speed and direction at six levels; an RM Young 8100 3D sonic anemometer that measures fast response winds; an NR Lite (Kipp \& Zonen) net radiometer that measures net radiation; a soil temperature probe (107B) that measures soil temperature at 10, 20 and $50 \mathrm{~cm}$ depths; a Texas electronics tipping bucket metric rain gauge (TE525) that measures rainfall amount; and a water content reflectometer (CS616-L) that measures soil moisture at 10,20 and $50 \mathrm{~cm}$ depths. The CS616 measures the volumetric water content of porous media (such as soil) using the time-domain measurement method, which consists in generating an electromagnetic pulse. The elapsed travel time and pulse reflection are then measured and used to calculate soil volumetric water content.

These data are collected from the reports of the Severe Thunderstorms Observation and Regional Modeling (STORM) program of the Department of Science and Technology (DST), Government of India. The sensors attached to the micrometeorological towers and the data measured are reported in Table I.

Table I. Used sensors and measured parameters in the towers at Kharagpur and Ranchi.

\begin{tabular}{ll}
\hline $\begin{array}{l}\text { Sensors installed in the towers } \\
\text { at Kharagpur and Ranchi }\end{array}$ & Parameters measured \\
\hline HMP45C-L sensors & Air temperature and relative humidity \\
\hline CS barometric pressure sensors & Atmospheric pressure \\
\hline RM Young wind anemometer $(05103-10-\mathrm{L})$ & Wind speed and directions \\
\hline NR Lite 2 net radiometer & Net radiation \\
\hline Tipping bucket rain gauge & Precipitation \\
\hline Soil temperature probe (107B) & Soil temperature at 10,20 and $50 \mathrm{~cm}$ depths at Kharagpur \\
\hline Water content reflectometer (CS616-L) & and 5,10, 20, 40 and $100 \mathrm{~cm}$ depths at Ranchi \\
\hline
\end{tabular}

${ }^{1} \mathrm{~A}$ larger description is available in section 4.

\section{Results and discussion}

The leading part of a propagating mesoscale convective storm system, arranged in a line, refers to the squall line (Gamache et al., 1982). The buoyant updraft associated with the squall line transports moisture and static energy from the boundary layer to the upper troposphere. These types of thunderstorm activities featuring squall lines are frequent during pre-monsoon seasons over the stations Kharagpur and Ranchi. A severe squall line passed over the station Kharagpur on April 26, 2007 at local time 16:30 IST (UTC + 05:30). The turbulent kinetic energy (TKE) or fluctuating kinetic energy is computed using frictional velocity (Eq. [4]) at different heights of the towers. The results show a sharp rise in TKE when the thunderstorm is just over the station and the observed value exceeds $90 \mathrm{~m}^{2} / \mathrm{s}^{2}$ at $50 \mathrm{~m}$ height over Kharagpur (Fig. 4). The same pattern is observed for the station Ranchi (Fig. 5) on a thunderstorm day (May 3, 2009) but the values of kinetic energy are lower $\left(12 \mathrm{~m}^{2} / \mathrm{s}^{2}\right.$ at $32 \mathrm{~m}$ height). 

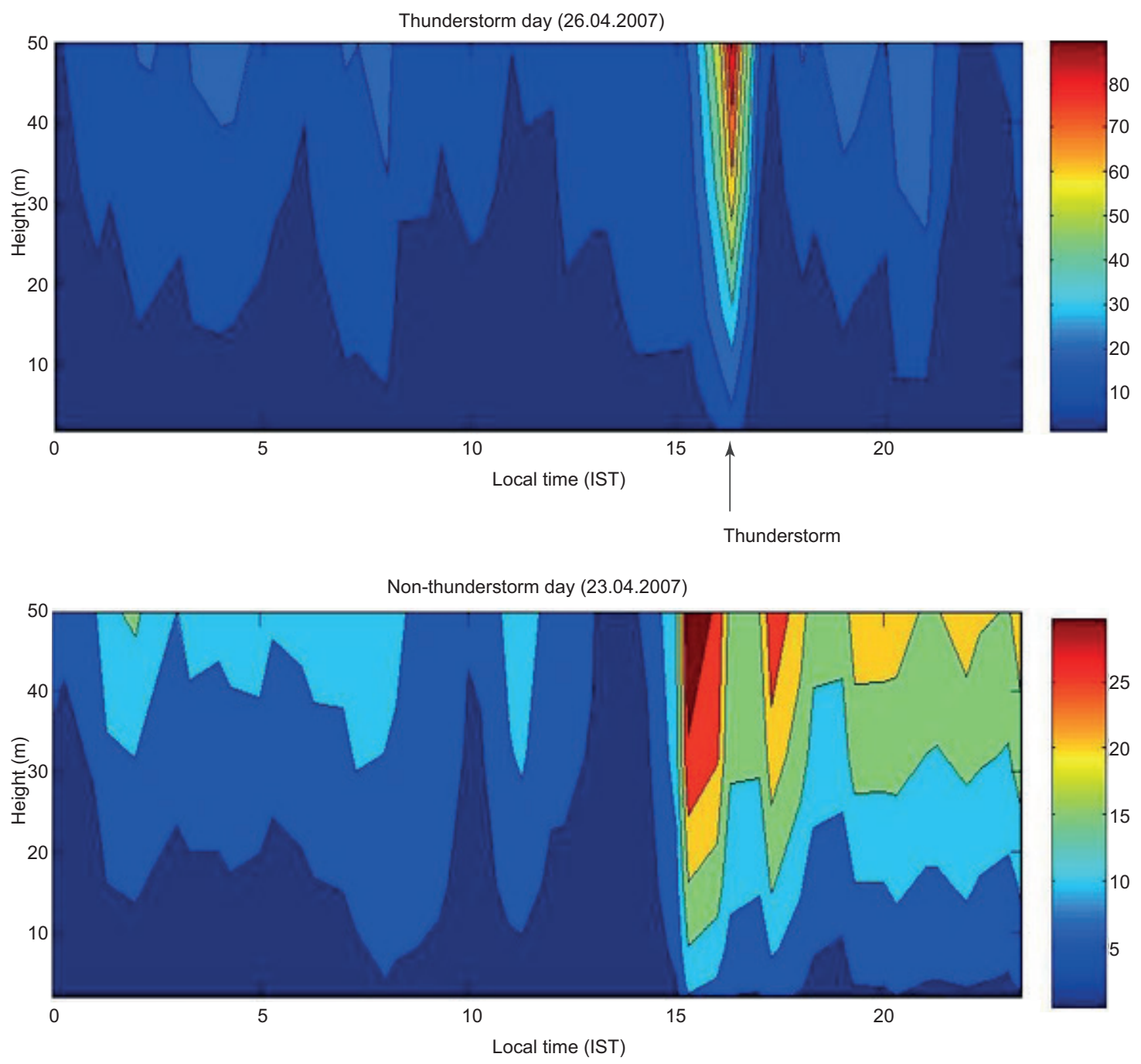

Fig. 4. Contour plots of turbulent kinetic energy $\left(\mathrm{m}^{2} / \mathrm{s}^{2}\right)$ within $50 \mathrm{~m}$ of the boundary layer on a severe thunderstorm day (April 26, 2007) and a non-thunderstorm day (April 23, 2007) over Kharagpur.

Different energy fluxes show some remarkable changes during thunderstorms. Near the surface (between 2 and $8 \mathrm{~m}$ ) the heat flux depicts a certain fall to the day's minimum $\left(-0.05^{\circ} \mathrm{K} \mathrm{m} / \mathrm{s}\right)$ just before the occurrence of thunderstorm and then increases to maximum when the squall passes over the station Kharagpur at 16:30 IST (Fig. 6). The value of heat flux over Ranchi shows day's maximum (0.078) while the thunderstorm passes through the station (Fig. 7). However, in the case of a non-thunderstorm day, the decrease was not so sharp and the negative values of the heat flux remained within $-0.025^{\circ} \mathrm{K} \mathrm{m} / \mathrm{s}$. On the other hand, the moisture flux shows a trend opposite to heat flux (Figs. 8-9). The moisture flux is observed to increase to maximum value at 15:00 IST and suddenly decrease during thunderstorm at 16:30 IST; the decreasing trend prevailed until 17:30 IST. This is because the rainfall was reported to occur from 16:00 to 17:00 IST due to thunderstorm over Kharagpur (Fig. 8). A sharp fall in moisture flux was observed when the thunderstorm passed over 

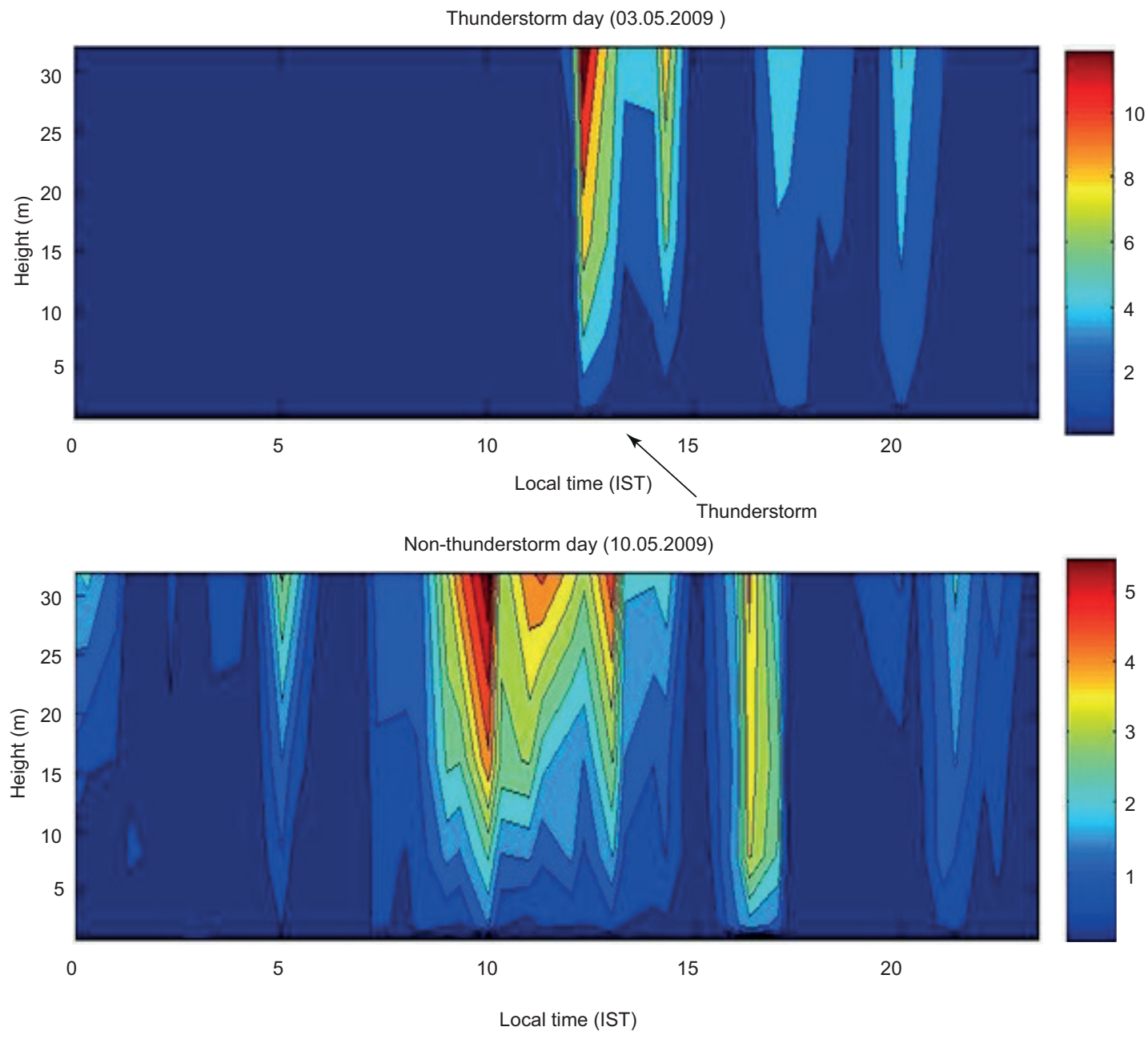

Fig. 5. Contour plots of turbulent kinetic energy $\left(\mathrm{m}^{2} / \mathrm{s}^{2}\right)$ within $32 \mathrm{~m}$ of the boundary layer on a severe thunderstorm day (May 3, 2009) and a non-thunderstorm day (May 10, 2009) over Ranchi.

Ranchi at 14:30 IST (Fig. 9). The duration of rainfall is shown with a dashed line in Figures 5 and 6. The fall of the moisture fluxes just before the thunderstorm can be linked to the microphysical aspects of the thundercloud. The moisture flux is observed to rise a few hours before thunderstorm occurrence due to the arrival of sea breeze from the Bay of Bengal. However, the formation of cloud condensation nuclei (CCN) with the available moisture just before the thunderstorm event causes drastic reduction of the moisture fluxes. The surface layer momentum flux (within 2 to $8 \mathrm{~m})$ showed a high peak $\left(0.177 \mathrm{~m}^{2} / \mathrm{s}^{2}\right)$ when the thunderstorm was just over the station at $16: 30$ IST (Fig. 10). A sudden increase in wind speed during thunderstorm resulted in the presence of high momentum flux within the surface layer. The observed momentum flux over Ranchi shows a greater value $\left(0.3 \mathrm{~m}^{2} / \mathrm{s}^{2}\right)$ during the thunderstorm on May 3, 2009 (Fig. 11). A variation of the Richardson number showed negative values few hours before the thunderstorm and attained a value of 0.25 when the storm crossed the station at 16:30 IST (Fig. 12); then increased suddenly to the maximum value of 4.88 at 17:30 IST and further decreased to a very low value at 18:30 IST. 


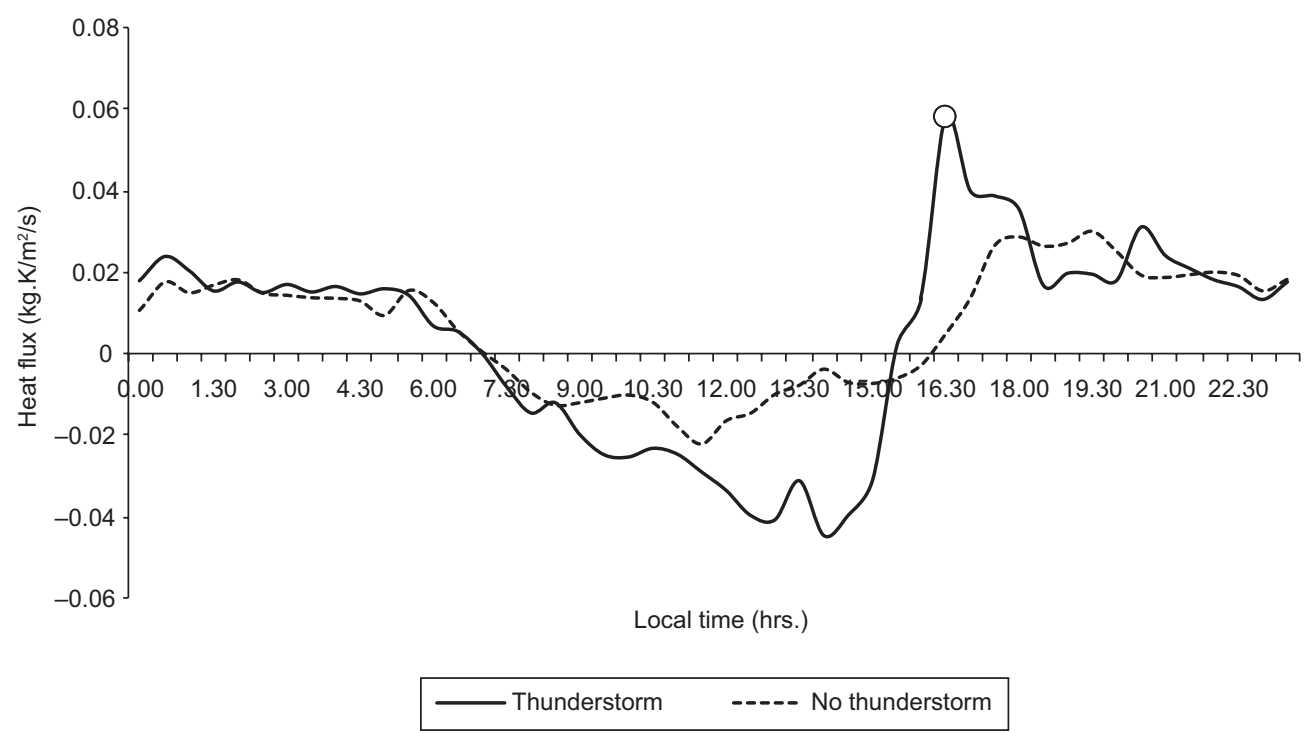

Fig. 6. Heat flux within a 2 to $8 \mathrm{~m}$ height on a thunderstorm day (April 26, 2007) (passage of the thunderstorm over the station is shown by an open circle) and a non-thunderstorm day (April 23, 2007) over Kharagpur.

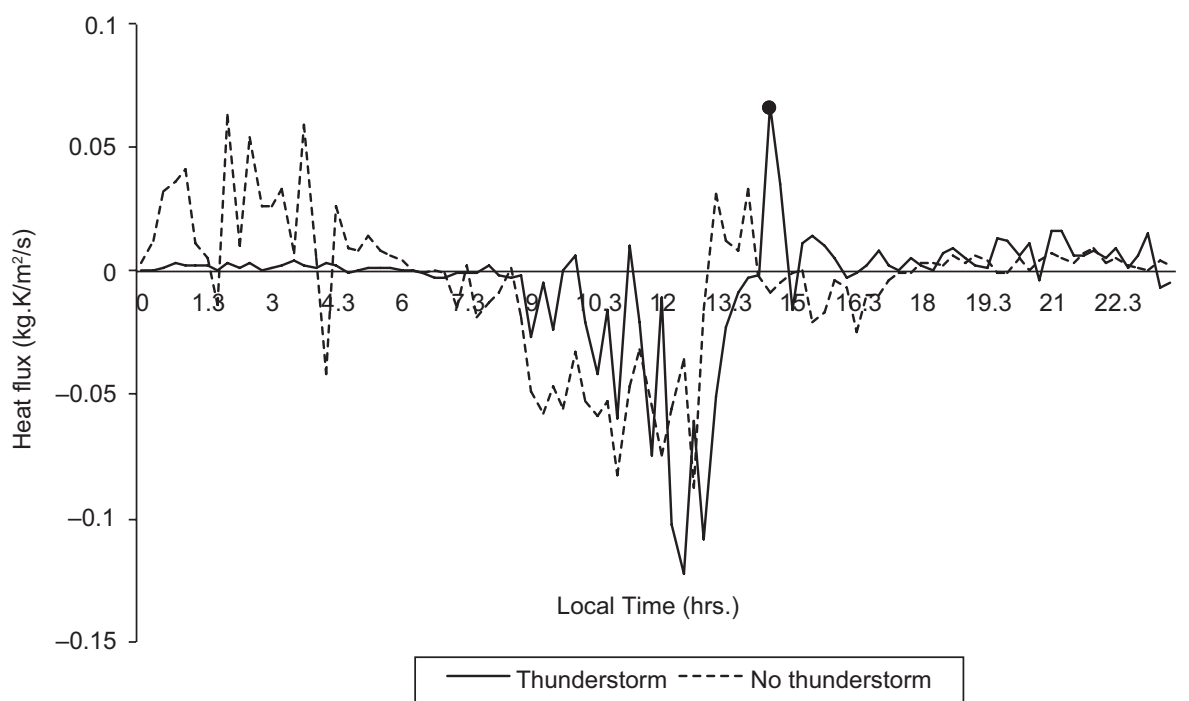

Fig. 7. Variation of heat flux within a 2 to $8 \mathrm{~m}$ height on a thunderstorm day (May 3 , 2009) (time of occurrence of the thunderstorm is marked by a dot) and a nonthunderstorm day (May10, 2009) over Ranchi. 


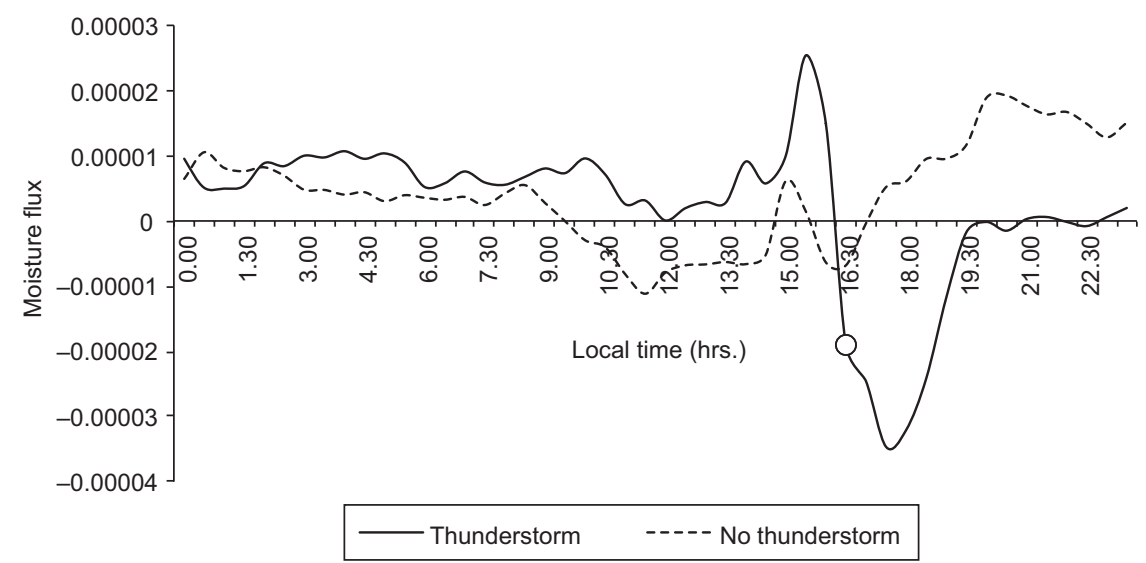

Fig. 8. Moisture flux within a 2 to $8 \mathrm{~m}$ height on a thunderstorm day (April 26, 2007) (passage of the thunderstorm over the station is shown by an open circle) and a non-thunderstorm day (April 23, 2007).

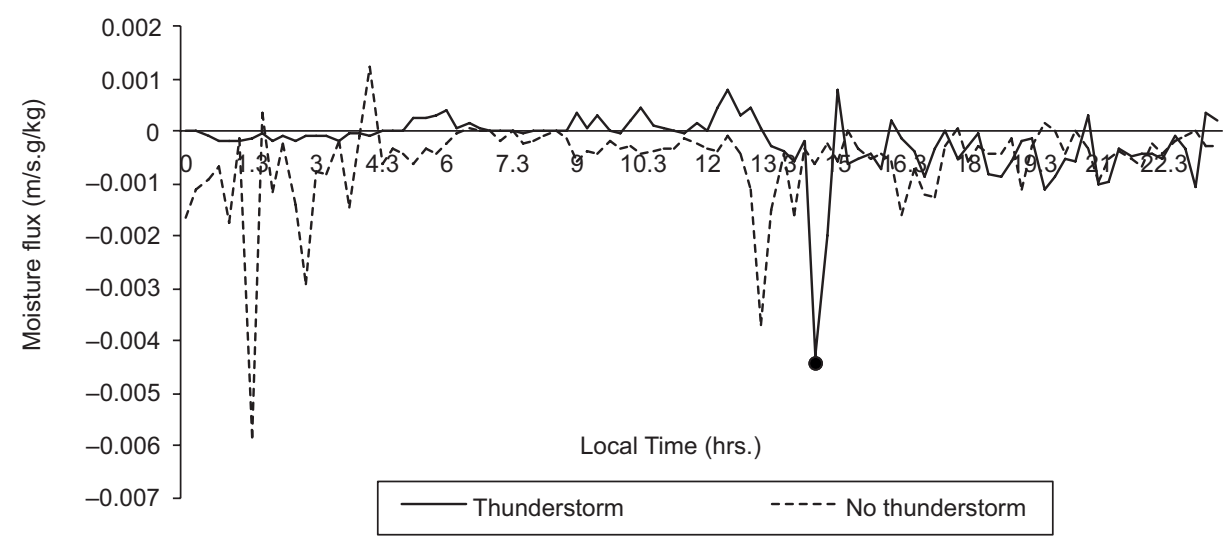

Fig. 9. Variation of moisture flux within a 2 to $8 \mathrm{~m}$ height on a thunderstorm day (May 3 , 2009) (time of occurrence of the thunderstorm is marked by a dot) and a non-thunderstorm day (May 11, 2009) over Ranchi.

Richardson number represents the ratio of buoyancy and shear. Just before the arrival of thunderstorm over the station, the shear dominates over buoyancy and the opposite occurs when the storm passes over the station. Variations of heat, moisture and momentum flux along with rainfall amount are plotted (Figs. 13-15) for a thunderstorm day on April 16, 2007, at Kharagpur. To make the rainfall amount value comparable with the fluxes, the actual rainfall (in $\mathrm{mm}$ ) is multiplied by $10^{-2}, 10^{-5}$ and $10^{-2}$ for the heat, moisture and momentum flux, respectively. Heat and momentum fluxes are increased along with rainfall as the thunderstorm approaches the station, whereas the moisture flux decreases as rainfall starts, which is quite obvious due to continuous loss of atmospheric moisture as rainfall.

The surface layer of the ABL thus responded differently and there are marked differences in its characteristics during thunderstorm and non-thunderstorm days. The presence of a pressure trough, low pressure areas and converging wind with adequate amount of moisture in the lower troposphere, 


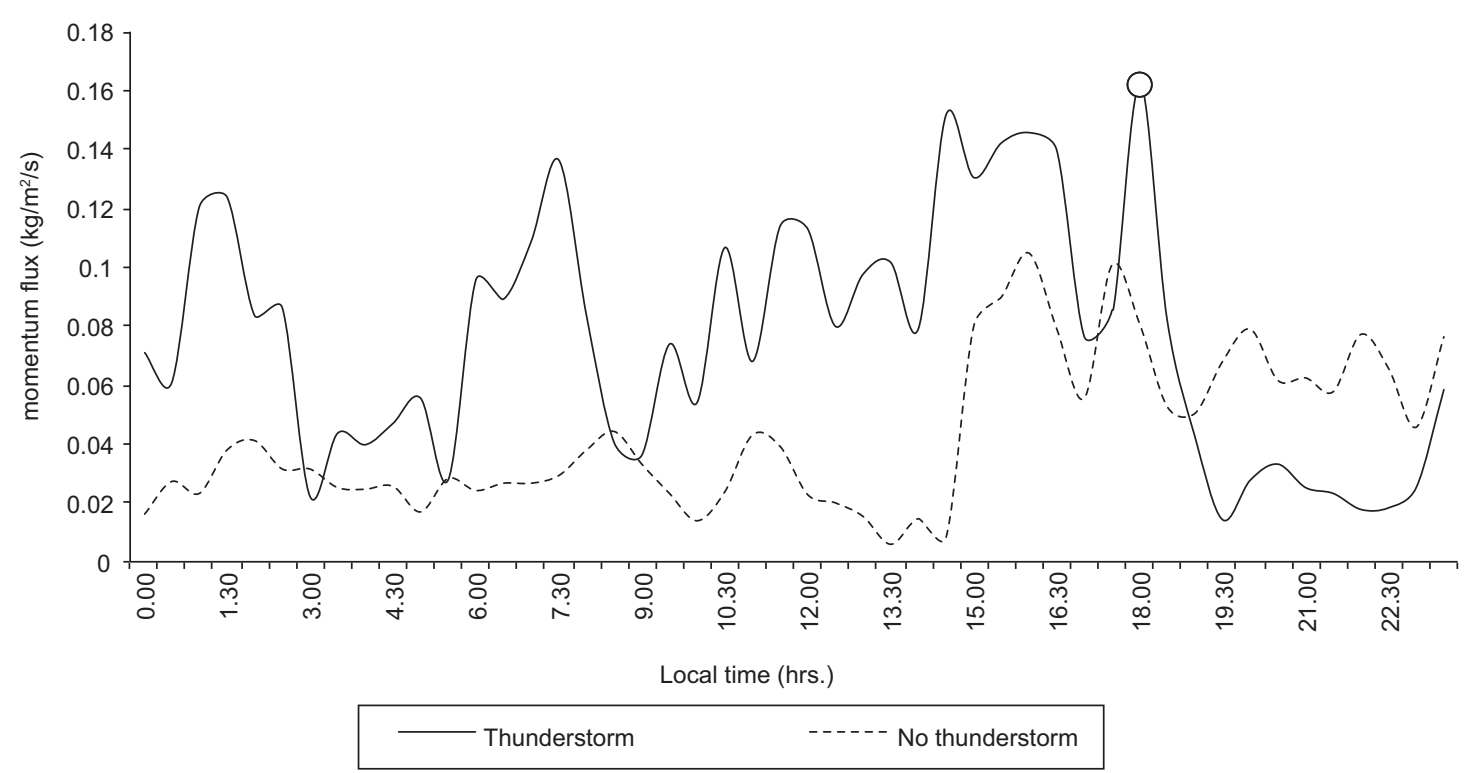

Fig. 10. Momentum flux within a 2 to $8 \mathrm{~m}$ height on a thunderstorm day (April 26, 2007) (passage of the thunderstorm over the station is shown by an open circle) and a non-thunderstorm day (April 27, 2007).

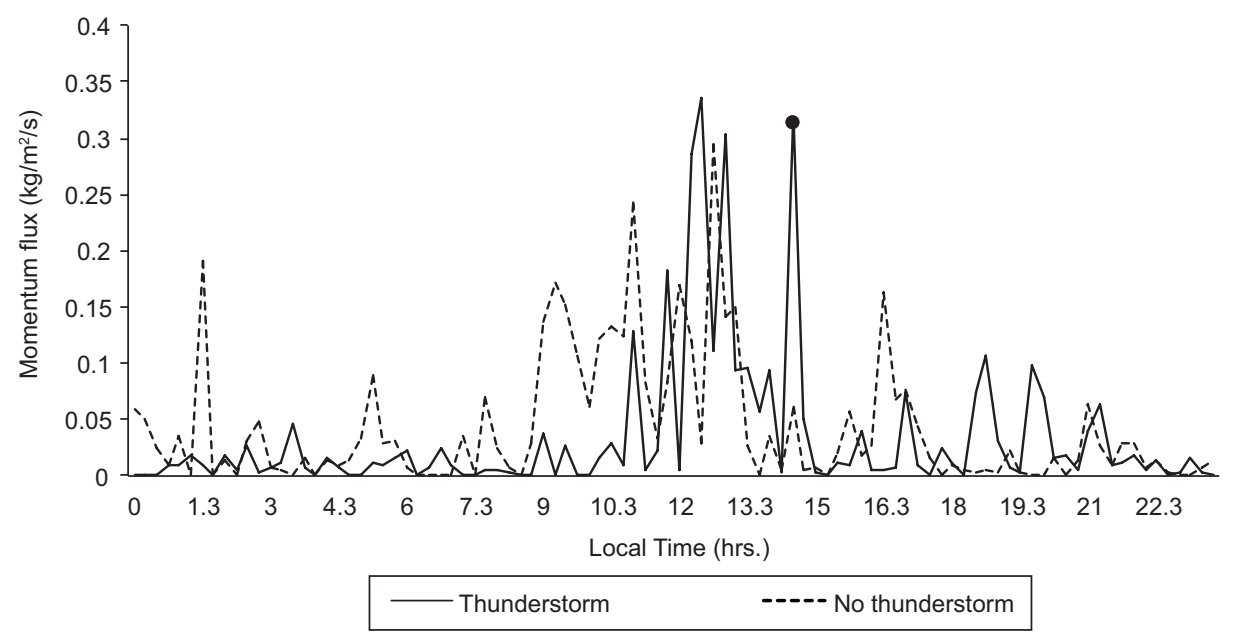

Fig. 11. Momentum flux within a 2 to $8 \mathrm{~m}$ height for a thunderstorm day (May 3, 2009) and a non-thunderstorm day (May 11, 2009) over Ranchi. 

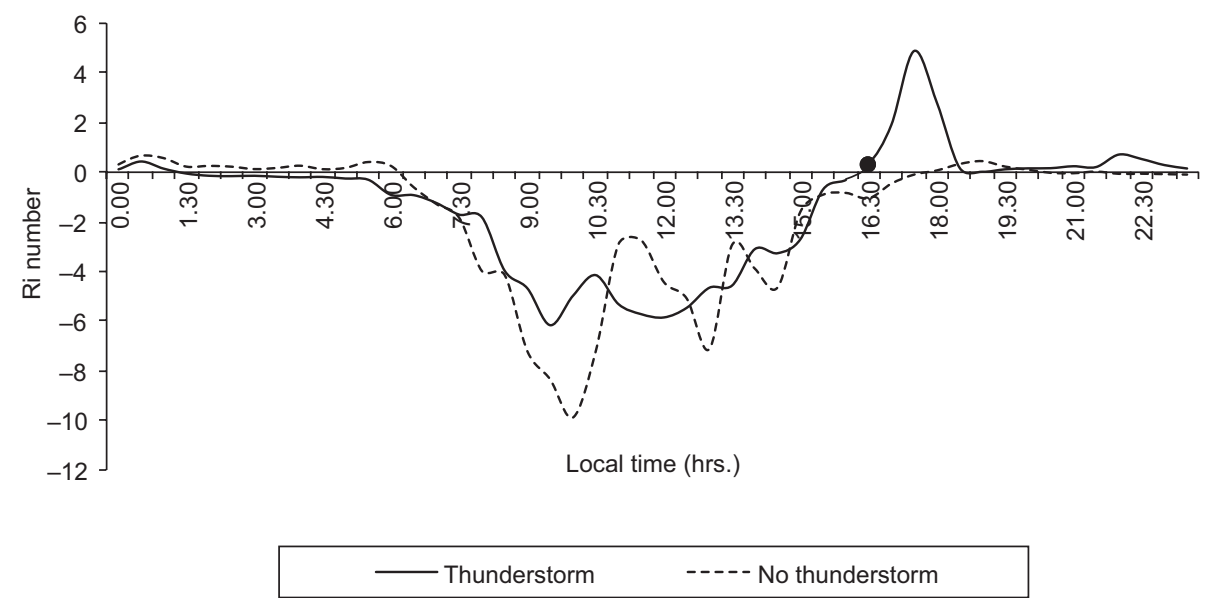

Fig. 12. $R i$ number within a 2 to $50 \mathrm{~m}$ height on a thunderstorm day (April 26, 2007) (time of occurrence of the storm is marked by a dot) and a non-thunderstorm day (April 23, 2007).

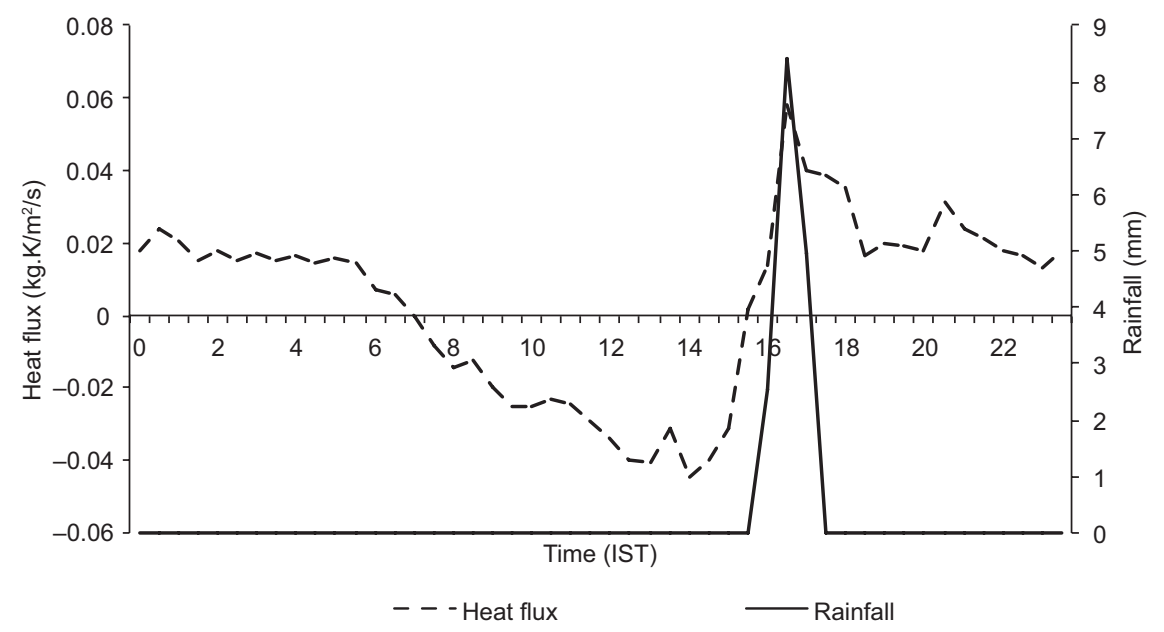

Fig. 13. Variation of rainfall and heat flux during a thunderstorm day (April 26, 2007) over Kharagpur. 


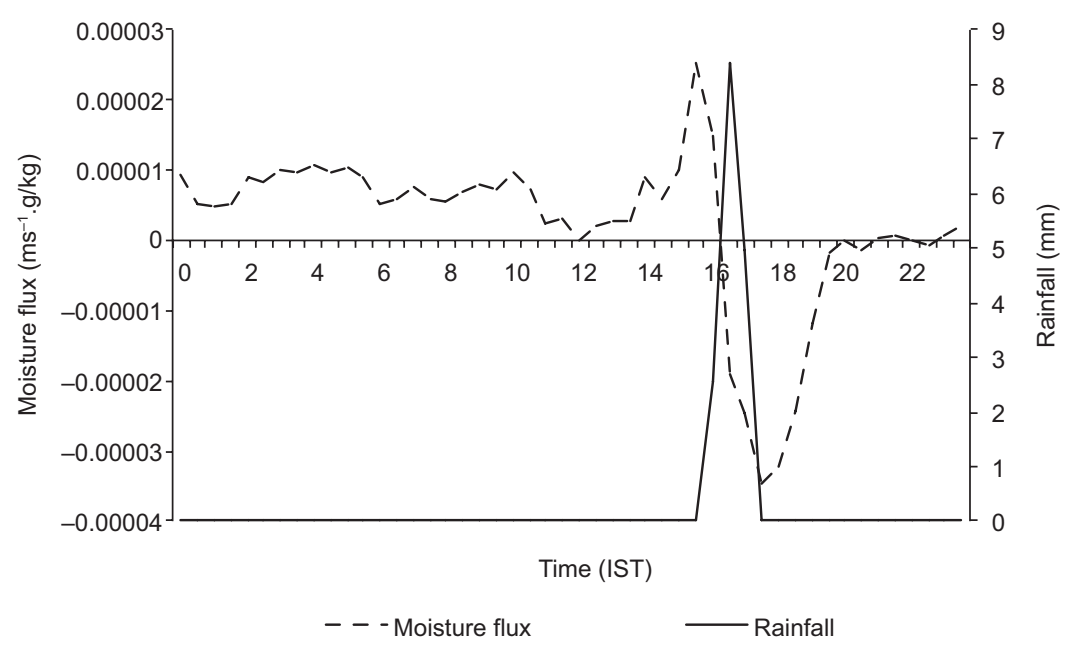

Fig. 14. Variation of rainfall and moisture flux during a thunderstorm day (April 26, 2007) over Kharagpur.

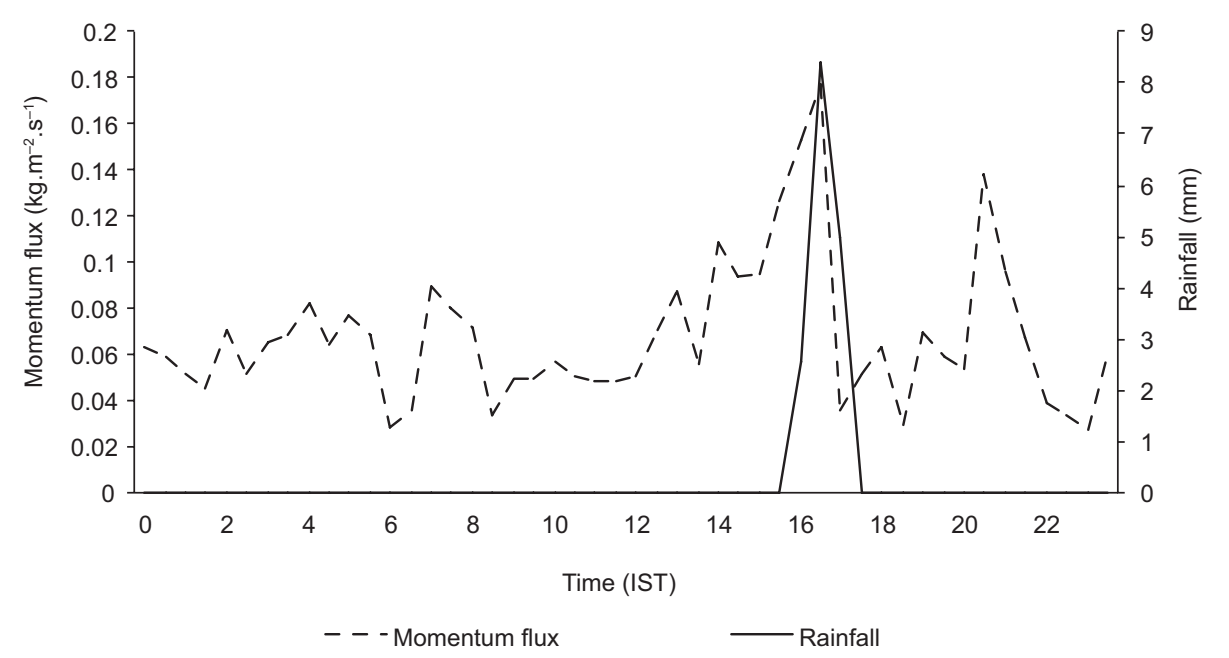

Fig. 15. Variation of rainfall and momentum flux during a thunderstorm day (April 26, 2007) over Kharagpur.

along with divergent flow in upper troposphere generally associated with upper tropospheric westerlies or tropical jet stream, are a very significant synoptic feature in the genesis of pre-monsoon (April, May) thunderstorms over this part of the country. The results reveal that the presence of such favorable synoptic situations enhanced the possibility of severe thunderstorm over the location. Analyses of $\theta$ and $\theta e$ show an interesting trend within the surface layer. A thunderstorm day over Kharagpur (April 26, 2007) reveals a variation in the ratio $\theta / \theta e$, which is different than a nonthunderstorm day (April 23, 2007) (Fig. 16). The value of the ratio $\theta / \theta e$ is observed to rise abruptly reaching the day's maximum just before the occurrence of a thunderstorm. A typical value of the ratio is identified to be around 0.86 during the passage of a thunderstorm. The day's minimum value of the ratio remains on the higher side $(0.74)$ for thunderstorm days compared to non-thunderstorm 

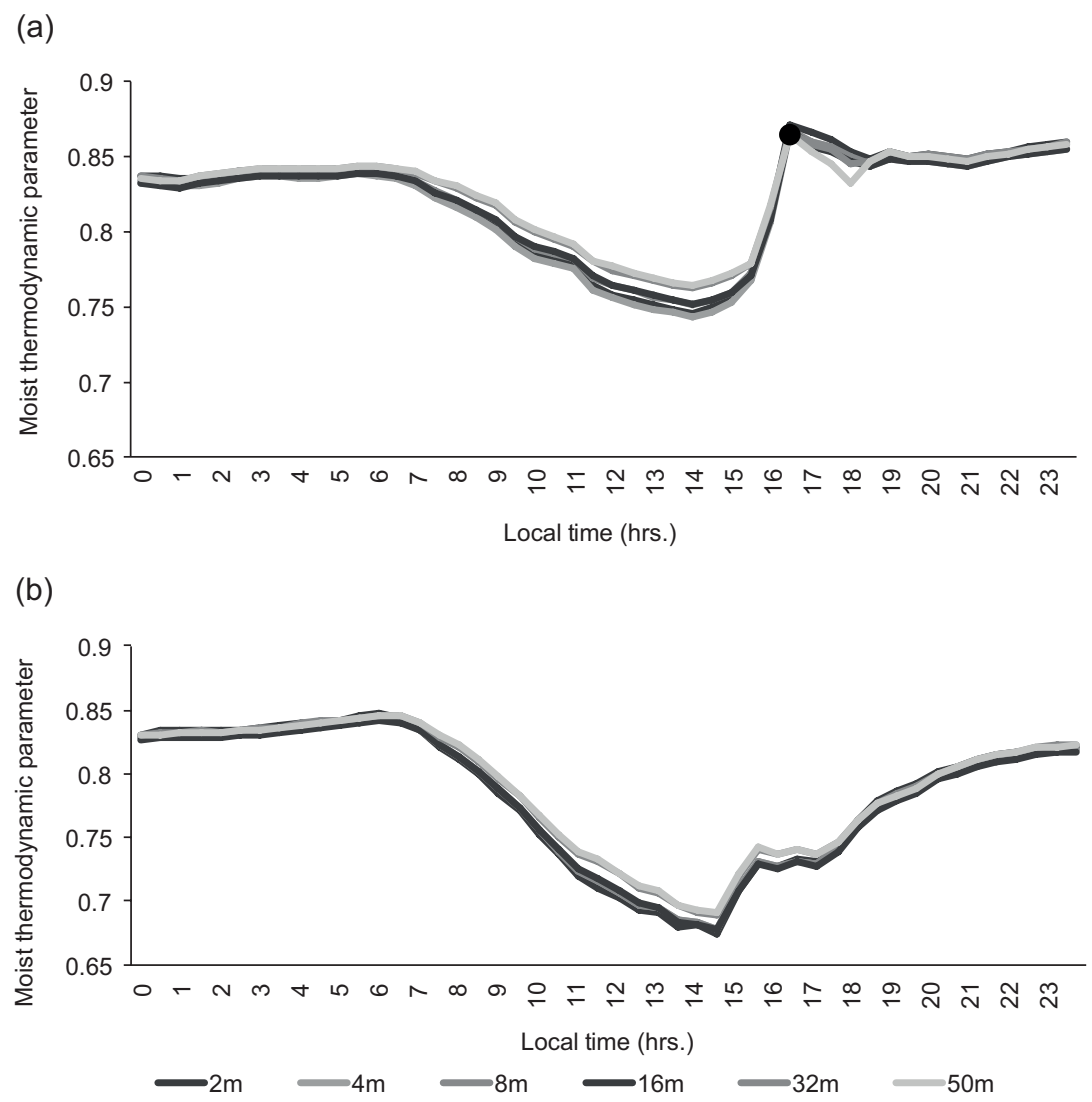

Fig. 16. Variation of the moist thermodynamic parameter during (a) a thunderstorm day (April 26, 2007) and (b) a non-thunderstorm day (April 23, 2007)) over the station Kharagpur (passage of the thunderstorm over the station is represented by a bold dot in panel [a]).

days $(\theta / \theta e=0.68)$. Over Ranchi, a typical thunderstorm day (May 3, 2009) shows the maximum value of $\theta / \theta e$ to be 0.88 just before the passage of the squall through the station (Fig. 17). A typical non-thunderstorm day (May 10, 2009) over Ranchi shows a fluctuating pattern (Fig. 17), but maxima never exceed 0.84 (which is a typical value just before a thunderstorm). The changes in the value of the ratio, as the storm approaches the station, are very specific. The maximum and minimum values of the ratio on various significant thunderstorm days along with some non-thunderstorm days over Kharagpur and Ranchi are given in Table II. The box-whisker plot in Figure 18 shows the variability of MTP $(\theta / \theta e)$ for thunderstorm and non- thunderstorm days over Kharagpur and Ranchi. Though the values share some common region, maximum and minimum values of MTPs on thunderstorm days are markedly different than those of non-thunderstorm days.

\section{Conclusion}

Real atmosphere is neither completely dry nor completely saturated. It remains somewhere in between. Just before the occurrence of thunderstorms the atmosphere becomes very dry (as reflected 
(a)

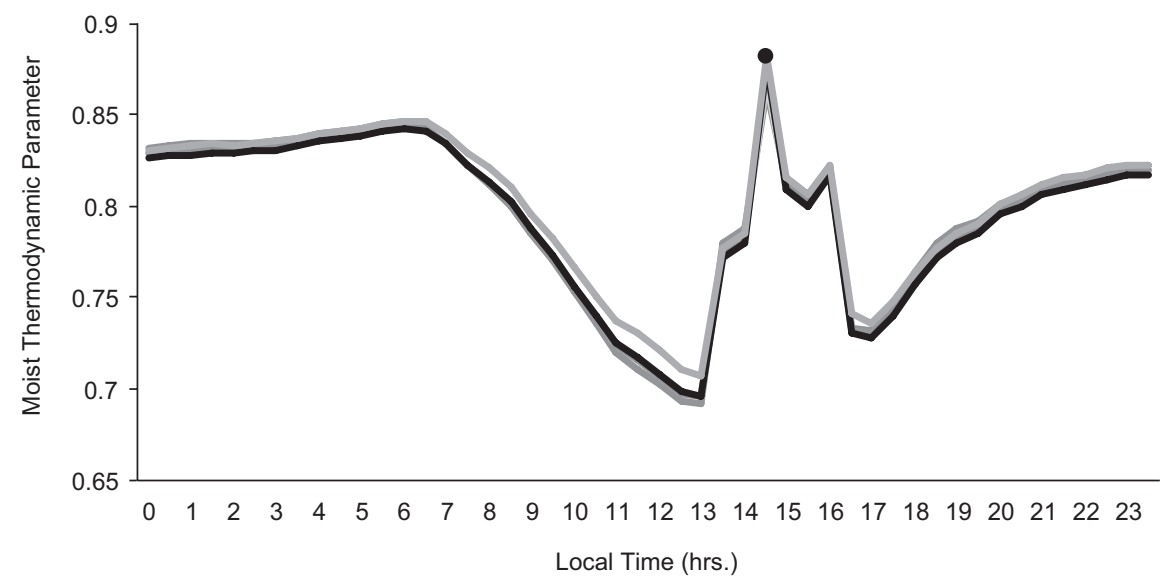

(b)

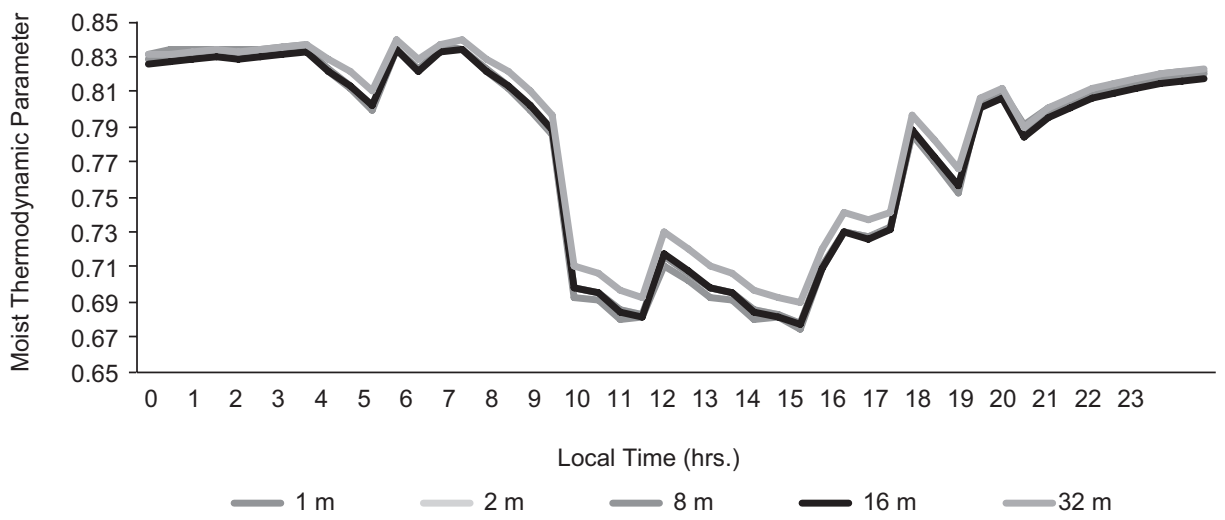

Fig. 17. Variation of moist thermodynamic parameter during (a) a thunderstorm day (May 3, 2009) and (b) a non-thunderstorm day (May 10, 2009) over the station Ranchi (passage of the thunderstorm over the station is represented by a bold dot in figure [a]).

by a high $\theta / \theta e$ ratio). The predictability of the passage of thunderstorms through the station can be estimated by proper quantification of the $\theta / \theta e$ ratio (herein 0.85 to 0.9 ), which can also be a predictive tool to sense the passage of thunderstorms through the selected stations. Surface layer responds differently on thunderstorm and non-thunderstorm weather conditions. The wind field plays a very crucial role at the inland station, Kharagpur. The study shows that the surface layer becomes turbulent when the mechanical turbulence dominates due to high wind speed during the thunderstorm. The transitions between turbulent and stable boundary layer can be observed during the changes in different stability parameters. TKE increases directly with the advancement of the thunderstorm towards the station. Different surface layer fluxes are computed using a gradient approach. After the sea breeze onset, the general trend is towards a decreasing momentum and heat fluxes with increasing tendency of moisture flux, which indicates a steady flow of cool moist marine air after the passage of the sea breeze over Kharagpur. The attempt is made in this study to understand the surface layer characteristics and its response to two completely different weather 
Table II. Maximum and minimum MTP values corresponding to different thunderstorm and non-thunderstorm days over Kharagpur and Ranchi.

\begin{tabular}{|c|c|c|c|c|}
\hline $\begin{array}{l}\text { Date } \\
\text { (dd.mm.уyуy) }\end{array}$ & Event and location & $\begin{array}{c}\text { Time of } \\
\text { event occurrence } \\
\text { (IST) }\end{array}$ & $\begin{array}{c}\text { Maximum MTP value } \\
\text { and time of occurrence } \\
\text { (IST) }\end{array}$ & $\begin{array}{l}\text { Minimum MTP value } \\
\text { and time of occurrence } \\
\text { (IST) }\end{array}$ \\
\hline 15.04.2007 & $\begin{array}{l}\text { No thunderstorm } \\
\text { over Kharagpur }\end{array}$ & --- & 0.83 at $06: 45$ & 0.66 at $13: 25$ \\
\hline 26.04.2007 & $\begin{array}{l}\text { Thunderstorm over } \\
\text { Kharagpur }\end{array}$ & $16: 30-16: 45$ & 0.87 at $16: 30$ & 0.74 at $12: 00$ \\
\hline 23.04.2007 & $\begin{array}{l}\text { No thunderstorm } \\
\text { over Kharagpur }\end{array}$ & --- & 0.84 at $07: 30$ & 0.67 at $15: 00$ \\
\hline 01.05.2009 & $\begin{array}{l}\text { No thunderstorm } \\
\text { over Ranchi }\end{array}$ & --- & 0.83 at $04: 30$ & 0.66 at $14: 30$ \\
\hline 03.05.2009 & $\begin{array}{l}\text { Thunderstorm over } \\
\text { Ranchi }\end{array}$ & $14: 30-14: 42$ & 0.88 at $14: 30$ & 0.74 at $13: 00$ \\
\hline 11.05.2009 & $\begin{array}{l}\text { Thunderstorm over } \\
\text { Kharagpur }\end{array}$ & $17: 30-17: 40$ & 0.86 at 1730 & 0.73 at $14: 30$ \\
\hline 10.05.2009 & $\begin{array}{l}\text { No thunderstorm } \\
\text { over Ranchi }\end{array}$ & --- & 0.84 at $06: 00$ & 0.67 at $15: 30$ \\
\hline 11.05.2009 & $\begin{array}{l}\text { Thunderstorm over } \\
\text { Ranchi }\end{array}$ & $13: 15-13: 26$ & 0.87 at $13: 15$ & 0.74 at $11: 35$ \\
\hline 15.09.2009 & $\begin{array}{l}\text { Thunderstorm over } \\
\text { Kharagpur }\end{array}$ & $18: 30-18: 48$ & 0.87 at $18: 30$ & 0.74 at $15: 40$ \\
\hline
\end{tabular}

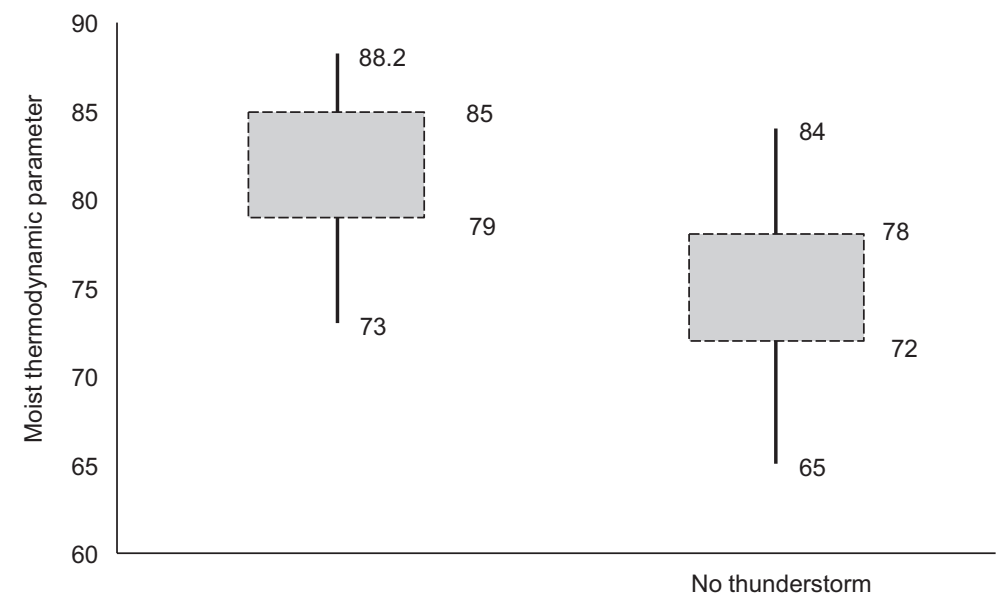

Fig. 18. Variability of the moist thermodynamic parameter $(\theta / \theta e)$ for thunderstorm and non-thunderstorm days obtained from the data analysis of Kharagpur and Ranchi towers.

events: thunderstorm and no thunderstorm. Observing the different patterns of TKE and other energy fluxes, or the temporal changes of various surface layer parameters, is very useful in further studies like boundary layer modeling and thunderstorm forecast over this stations (Kharagpur and Ranchi). The abrupt rise in the value of $\theta / \theta e$ ratio just before the thunderstorm, reaching the 
day's highest value is certainly a good indicator of the passage of thunderstorm through the site. Also, before reaching the maximum value on thunderstorm day, the $\theta / \theta e$ ratio reaches the day's minimum, which remains higher than the non-thunderstorm day's minimum value. Thus, with a proper quantification, the $\theta / \theta e$ could be a good indicator for confirming the passage of thunderstorms through a station. Such definite changes are not observed on non-thunderstorm days. It is certain that more analyses with more data sets are needed to establish the importance of the ratio $\theta / \theta e$ in understanding the prevalence of thunderstorms.

\section{Acknowledgements}

The first author acknowledges IIT Kharagpur and BIT Mesra along with the India Meteorological Department (IMD) and the Department of Science and Technology, New Delhi, for making the data available under STORM Program. Financial support rendered by the Council of Scientific and Industrial Research (CSIR), Government of India, is also acknowledged.

\section{References}

Blackadar A. K., 1962. The vertical distribution of wind and turbulent exchange in a neutral atmosphere. J. Geophys. Res. 67, 3095-3102.

Brown A. R., 1996. Evaluation of parameterization schemes for the convective boundary layer using large-eddy simulation results. Bound.-Lay. Meteorol. 81, 167-200.

Businger J. A., J. C. Wyngaard, Y. Izumi and E. F. Bradley, 1971. Flux-profile relationships in the atmospheric surface layer. J. Atmos. Sci. 28, 181-189.

Cao Z. H. and H. R. Cho, 1995. Generation of moist potential vorticity in extra tropical cyclones. J. Atmos. Sci. 52, 3263-3281.

Chaudhuri S., 2008a. Preferred type of cloud in the genesis of severe thunderstorms - a soft computing approach. Atmos. Res. 88, 149-156.

Chaudhuri S., 2008b. Identification of the level of downdraft formation during severe thunderstorms: A frequency domain analysis. Meteorol. Atmos. Phys. 102, 123-129.

Chaudhuri S. and A. Middey, 2009. Applicability of bipartite graph model for thunderstorms forecast over Kolkata. Advances in Meteorology 2009, 1-12, doi:10.1155/2009/270530.

Chaudhuri S., 2010. Convective energies in forecasting severe thunderstorms with one hidden layer neural net and variable learning rate back propagation algorithm. Asia-Pac. J. Atmos. Sci. 46, 173-183.

Chaudhuri S. and A. Middey, 2011. Nowcasting thunderstorms with graph spectral distance and entropy estimation. Meteorol. Appl., 18, 238-249.

Deardorff J. W., 1974. Three-dimensional numerical study of the height and mean structure of a heated planetary boundary layer. Bound.-Lay. Meteorol. 7, 81-106.

Frank H. P., 1994. Boundary layer structure in two fronts passing a tower. Meteorol. Atmos. Phys. 53, 95-109.

Gamache J. F. and R. A. Houze, 1982. Mesoscale air motions associated with a tropical squall line. Mon. Wea. Rev. 110, 118-135.

Gao S., T. Lei and Y. Zhou, 2002a. Moist potential vorticity anomaly with heat and mass forcings in torrential rain systems. Chinese Phys. Lett. 19, 878-880. 
Gao S., T. Lei, Y. Zhou and M. Dong, 2002b. Diagnostic analysis of moist potential vorticity anomaly in torrential rain systems. Journal of Applied Meteorological Science 13, 662-680.

Gao S., X. Wang and Y. Zhou, 2004. Generation of generalized moist potential vorticity in a frictionless and moist adiabatic flow. Geophy. Res. Lett. 31, doi:10.1029/2003GL019152.

Grant A. L. M., 1986. Observations of boundary layer structure made during the 1982 KONTUR experiment. Quart. J. Roy. Meteor. Soc. 112, 825-841.

Hertenstein R. F. A. and W. H. Schubert, 1991. Potential vorticity anomalies associated with squall lines. Mon. Weather Rev. 119, 1663-1672.

Hong S. Y. and H. L. Pand, 1996. Nonlocal boundary layer vertical diffusion in a medium-range forecast model. Mon. Weat. Rev 124, 2322-2339.

Kaimal J. C., J. C. Wyngaard, D. A. Haugen, O. R. Cotr, Y. Izumi, S. J. Caughey and J. C. Readings, 1976. Turbulence structure in the convective boundary layer. J. Atmos. Sci. 33, 2152-2169.

Kang S. L., 2009. Temporal oscillations in the convective boundary layer forced by mesoscale surface heat-flux variations. Bound.-Lay. Meteorol. 132, 59-81.

Lohar D., B. Pal and B. Chakravarty, 1994. Sea breeze activity at an inland station Kharagpur. A case study. Bound.-Lay. Meteorol. 67, 427-434.

Manohar G. K., S. S. Kandalgaokar and M. I. R. Tinmaker, 1999. Thunderstorm activity over India and Indian south-west monsoon. J. Geophys. Res. 104, 4169-4188, doi:10.1029/98JD02592.

Nieuwstadt F. T. M. and R. A. Brost, 1986. The decay of convective turbulence. J. Atmos. Sci. 43, 532-546.

Panofsky H.A. and J. A. Dutton, 1984. Atmospheric turbulence. Models and methods for engineering applications. New York: Wiley-Interscience, $397 \mathrm{pp}$.

Robinson W. A., 1989. On the structure of potential vorticity in baroclinic instability. Tellus A 41, 275-284.

Rotunno R. J., B. Klemp and M. L. Weisman, 1988. A theory for strong, long-lived squall lines. J. Atmos. Sci. 45, 463-485.

Sorbjan Z., 2008. Local scales of turbulence in the stable boundary layer. Bound.-Lay. Meteorol. 127, 261-271.

Stull R. B., 1988. An introduction to boundary layer meteorology. Dordrecht: Kluwer Academic Publishers, $666 \mathrm{pp}$.

Sutton O. G., 1953. Micrometeorology. New York: McGraw-Hill, 333 pp.

Zhou Y., L. Liu and G. Deng, 2009. Comparisons of the generalized potential temperature in moist atmosphere with the equivalent potential temperature in saturated moist atmosphere. Advances in Meteorology 2009, doi:10.1155/2009/105265. 